\title{
The Prevalence of Hepatitis C Virus Infection and Its Related Risk Factors Among the Rural Population of Fars Province, Southern Iran
}

\author{
Mohammad Reza Fattahi ${ }^{1}$;Alireza Safarpour ${ }^{1}$; Masood Sepehrimanesh ${ }^{1}$; Seyed Mohammad \\ Kazem Hosseini Asl ${ }^{1}$; Faezeh Mohamaddoust ${ }^{1, *}$ \\ ${ }^{1}$ Gastroenterohepatology Research Center, Shiraz University of Medical Sciences, Shiraz, IR Iran \\ *Corresponding Author: Faezeh Mohamaddoust, Gastroenterohepatology Research Center, Shiraz University of Medical Sciences, Shiraz, IR Iran. Tel: +98-7136474263; +98-9171172347, \\ E-mail:gehrcshiraz@gmail.com
}

Received: October 20, 2014; Revised: December 1, 2014; Accepted: January 17, 2015

\begin{abstract}
Background: Hepatitis C virus (HCV) infection is a major blood-borne infection with silent epidemic, major global public health problem and diverse prevalence worldwide.

Objectives: This study aimed to evaluate the prevalence of HCV infection and related risk factors in the general population of two villages, Farmashkan and Akbarabad, of the Kavar City in Fars Province, Iran.

Patients and Methods: A34-month cross-sectional study was performed on all people of the villages aged $\geq 7$ years from July 2007 to April 2010. Demographic information and history of HCV-related risk factors were extracted from their medical records. For each participant, the serum anti-HCV IgG was assessed by the commercial enzyme-linked immunosorbent assay (ELISA) kits.

Results: A total of 6095 participants (36.4\% male and 65.6\% female) with the mean age of 92 (7-95) and mean \pm SD of $34.6 \pm 17.3$ years were included in this study. Fifteen persons ( $0.24 \%$ ) were detected as HCV-positive and the highest prevalence was seen in age $\leq 12$ years old ( $1 \%$ ). A significant association was only detected between blood transfusion and HCV infection; therefore, those persons with history of blood transfusion had 15-fold higher risk for HCV seropositivity (odds ratio 15.54, 95\% CI = 4.89-49.41).

Conclusions: Our reported rate of HCV seropositivity is similar to the previous Iranian reports. However, future evaluations should be focused on the Polymerase Chain Reaction method for the detection of HCV and determining and evaluating of other related risk factors. Moreover, more attention should be paid to blood donors as a reservoir population of HCV.
\end{abstract}

Keywords:HCV; ELISA; Blood Transfusion; Rural Population; Iran

\section{Background}

Hepatitis $\mathrm{C}$ virus (HCV) is an enveloped, single-stranded ribonucleic acid (RNA) virus with positive polarity. This virus is one of the most important pathogens of the human and is able to cause mild to severe liver diseases. The virus is a member of the hepaciviruses genus in the Flaviviridae family (1). Hepatitis C virus infection is a major blood-borne infection worldwide, with a silent epidemiology, that it has reached pandemic proportions (2). The chronic infection with HCV, remains a troublesome health problem worldwide, which approximately $3 \%$ of the population suffering from it. Its prevalence is higher in some countries of Asia and Africa and approximately $14.5 \%$ in Egypt (3-5). In developing countries, the chronic hepatitis $\mathrm{C}$ is the most prominent cause of liver cirrhosis, hepatocellular carcinoma and liver transplantation (6). However, the epidemiological pattern of $\mathrm{HCV}$ is still obscure $(7,8)$. Available estimates indicate that worldwide there were 54,000 deaths and 955,000 disability- adjusted lifeyears associated with acute HCV infection (4). The main routes of transmission in HCV are exposure to infected blood or blood product, intravenous drug use, infected medical equipment, tattooing, needle stick, hemodialysis, sexual activity and organ transplantation $(2,3,5)$.

The prevalence of anti-HCV from population-based studies is used to compare HCV infection levels globally. Hepatitis C virus infected an estimated 185 million people worldwide and is a significant cause of morbidity and mortality. Also, in developed countries, HCV predominantly infects people who inject drugs (9). Peoples in some closed settings such as prisons, jails, juvenile detention facilities, pretrial detention centers, and extrajudicial detention centers for people who use drug showed higher prevalence of HCV (10). However, it seems that the prevalence of this virus in the general population of Iran is less than $1 \%$ (11), which is approximately lower than the reports of the neighbor countries. The prevalence of $\mathrm{HCV}$ in the general population of different countries of the developed world around Iran has been reported to be between 0.9 and $4 \%$ (11). The difference observed in dif-

Copyright ( 2015, Kowsar Corp. This is an open-access article distributed under the terms of the Creative Commons Attribution-NonCommercial 4.0 International License (http://creativecommons.org/licenses/by-nc/4.0/) which permits copy and redistribute the material just in noncommercial usages, provided the original work is properly cited. 
ferent populations may be due to laboratory and selection methods. Also, it seems that there are differences between urban and rural population. There are no previous reports about the prevalence of HCV in rural population of Iran and due to the differences in HCV-related risk factors between these two populations, performing of the study on the prevalence of HCV in the rural population is seriously needed.

\section{Objectives}

This study was designed to determine the prevalence of anti-HCV antibody in general population of two villages, Farmashkan and Akbarabad, of the Kavar city in Fars Province, Iran, and evaluate the related risk factors in these areas. Moreover, the possible associations between all risk factors with anti-HCV antibody prevalence were also evaluated in this population.

\section{Patients and Methods}

The present study is a part of Kavar cohort study (K.C.S), which is started from 2006 in Kavar town with about 71856 populations. This town is located in 35 kilometer southeast of Shiraz, the capital of Fars Province, Iran. Gastroenterohepatology and Endocrine Research Centers affiliated to Shiraz University of Medical Sciences are implementing K.C.S. From the start of K.C.S till now, all peoples are followed every two years. In the original cohort study, demographic and anthropometric characteristics of participants are documented in the questionnaire. In a cross-sectional study, which approved in Ethical Committee of Shiraz University of Medical Sciences, by using Cochran formula and assuming $\mathrm{p}=0.03, \mathrm{q}=0.97, \mathrm{~d}=0.01$ and $\alpha=0.95$, the sample size of 1049 was calculated. Statistical power for this study was 0.95 . For better performing of the study we used census method sampling and therefore, blood samples of all of the Iranian peoples aged $\geq 7$ years old in the two villages, Farmashkan and Akbarabad of the Kavar City in Fars Province, Iran, which referred to the K.C.S Center were used. Our inclusion criteria were age equal or more than 7 years and using no medication for the HCV treatment. Our study had no exclusion criteria except voluntary withdrawal from the study. Demographic information included age, gender, marital status, occupation, history of blood and its product transfusion, hemodialysis, organ transplantation, dental procedure, accident, war injury, tattooing, injection drug use, addiction, alcohol use, personal or family history of liver disease, imprisonment, extramarital sexual contact, hepatitis B virus (HBV) vaccination, concomitant diseases and its symptoms were extracted from their medical records.

The blood samples $(10 \mathrm{~mL})$ were cooled on ice and taken to a specialized laboratory affiliated to Gastroenterohepatology Research Center, Shiraz University of Medical Sciences, Shiraz, Iran. The blood samples were centrifuged at $3500 \mathrm{rpm}$ for $15 \mathrm{~min}$ at $4^{\circ} \mathrm{C}$ and the serum was separated and stored at $-70^{\circ} \mathrm{C}$ until further analysis. The serum IgG antibody against $\mathrm{HCV}$ was determined using a third-generation indirect enzyme immunoassay (EIA) kit (Acon Laboratories, Inc, USA). This test can detect various subtypes of $\mathrm{HCV}$ antibodies using the recombinant antigens specific for core, NS3, NS4 and NS5. The clinical sensitivity and specificity of this kit are $>99.9 \%$ and $99.8 \%$, respectively.

\subsection{Statistical Analysis}

Data were reported as frequency and percentage and analyzed using SPSS software version 17.0 (Washington, USA) for Windows. Qualitative data were analyzed by chi-square and Fisher's exact tests to find any association between risk factors and HCV-antibody positivity. An independent samples t test was used to compare the age variable between the two villages. A P value $<0.05$ was used to indicate a statistically significant difference.

\section{Results}

A total of 6095 participants with age range of 88 years (7-95 years) and mean \pm standard deviation of $34.58 \pm$ 17.29 years, including 2218 males (36.4\%) and 3877 females (63.6\%) were enrolled in this study. A statistically significant difference was observed regarding the age of persons between the two villages (3393 and 2702 participants with age of $32.62 \pm 16.52$ and $36.93 \pm 17.90$ years from Akbarabad and Farmashkan, respectively, P $<0.001)$. Age groups, marital status, jobs/positions and other historical information are presented in Figure 1. Most of our participants were in the age range of 21-35 years (33.5\%), married (56.1\%), and unemployed (51.9\%) and had the history of dental procedure. Overall, 15 out of the 6095 participants, 8 female and 7 male subjects, were anti-HCV positive (0.25\%). Although, anti-HCV antibody prevalence was two in 1000 participants; however, seroprevalence of HCV in children was four times greater than general population and was $1 \%$. Frequency and percentage of the person's anti-HCV antibody status based on the age groups, marital status, jobs/position and related risk factors are presented in Table 1. Among them, 12 persons were symptom-free and only 3 persons were afflicted with fatigue and mild anorexia. One of them also had abdominal pain. Despite the HBV vaccination, two children (13.3\%) had the concomitant Hbs-Ag positivity and HBc-Ab negativity.

Comparisons of the effects of gender, marital status, age and history of blood transfusion, dental procedure, accident and imprisonment on the frequency of anti-HCV antibody are presented in Table 2 . Only a significant relationship was detected between a history of blood transfusion and the prevalence of $\operatorname{HCV}(\mathrm{P}<0.001)$. Also, persons with history of blood transfusion had 15fold higher risk for anti-HCV positivity (OR: 15.54, 95\% CI: 4.89-49.41). 
Fattahi MR et al.


Figure 1. Demographic Information About Rural Population of This Study

\begin{tabular}{|c|c|c|c|}
\hline & \multicolumn{2}{|c|}{ Frequency of Anti-HCV Antibody } & \multirow[t]{2}{*}{ PValue } \\
\hline & Positive & Negative & \\
\hline Villages & & & 0.467 \\
\hline Akbarabad & $12(0.3)$ & $3393(99.7)$ & \\
\hline Farmashkan & $3(0.1)$ & $2702(99.9)$ & \\
\hline Gender & & & 0.428 \\
\hline Male & $7(0.3)$ & $2211(99.7)$ & \\
\hline Female & $8(0.2)$ & $3869(99.8)$ & \\
\hline Marital status & & & 1.000 \\
\hline Single & $6(0.2)$ & $2530(99.8)$ & \\
\hline Married & $9(0.3)$ & $3412(99.7)$ & \\
\hline Divorced & $0(0)$ & $19(100)$ & \\
\hline Widowed & $0(0)$ & $119(100)$ & \\
\hline Age, $y$ & & & ND \\
\hline$\leq 12$ & $3(1.0)$ & $310(99.0)$ & \\
\hline $13-20$ & $3(0.3)$ & $1150(99.7)$ & \\
\hline $21-35$ & $2(0.1)$ & $1985(99.9)$ & \\
\hline $36-50$ & $4(0.3)$ & $1369(99.7)$ & \\
\hline$\geq 51$ & $3(0.3)$ & $1099(99.7)$ & \\
\hline Jobs/positions & & & ND \\
\hline Student & $5(0.3)$ & $1484(99.7)$ & \\
\hline Self-employed & $4(0.3)$ & $1293(99.7)$ & \\
\hline Employed & $0(0)$ & $101(100)$ & \\
\hline Unemployed & $6(0.2)$ & $3101(99.8)$ & \\
\hline Blood transfusion & $4(2.8)$ & $139(97.2)$ & $<0.001$ \\
\hline Accident & $1(0.3)$ & $296(99.7)$ & 0.528 \\
\hline Dental procedure & $12(0.3)$ & $3940(99.7)$ & 0.285 \\
\hline Tattooing & $0(0)$ & $189(100)$ & NP \\
\hline Intravenous drug abuse & $0(0)$ & $4(100)$ & NP \\
\hline Imprisonment & $1(1.2)$ & $81(98.8)$ & 0.184 \\
\hline War injury & $0(0)$ & $37(100)$ & NP \\
\hline Extramarital sexual activity & $0(0)$ & $15(100)$ & NP \\
\hline Alcohol using & $0(0)$ & $18(100)$ & NP \\
\hline Opioid using & $0(0)$ & $75(100)$ & NP \\
\hline Liver disease & $0(0)$ & $149(100)$ & NP \\
\hline Dialysis & $0(0)$ & $0(0)$ & NP \\
\hline Organ transplant & $0(0)$ & $0(0)$ & NP \\
\hline
\end{tabular}

a Abbreviations: ND; not determined, NP; not performed.

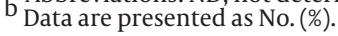


Table 2. Comparison of the Effects of Different Categories and Main Risk Factors on the Frequency and Percentage of Anti-HCV Antibody a, b

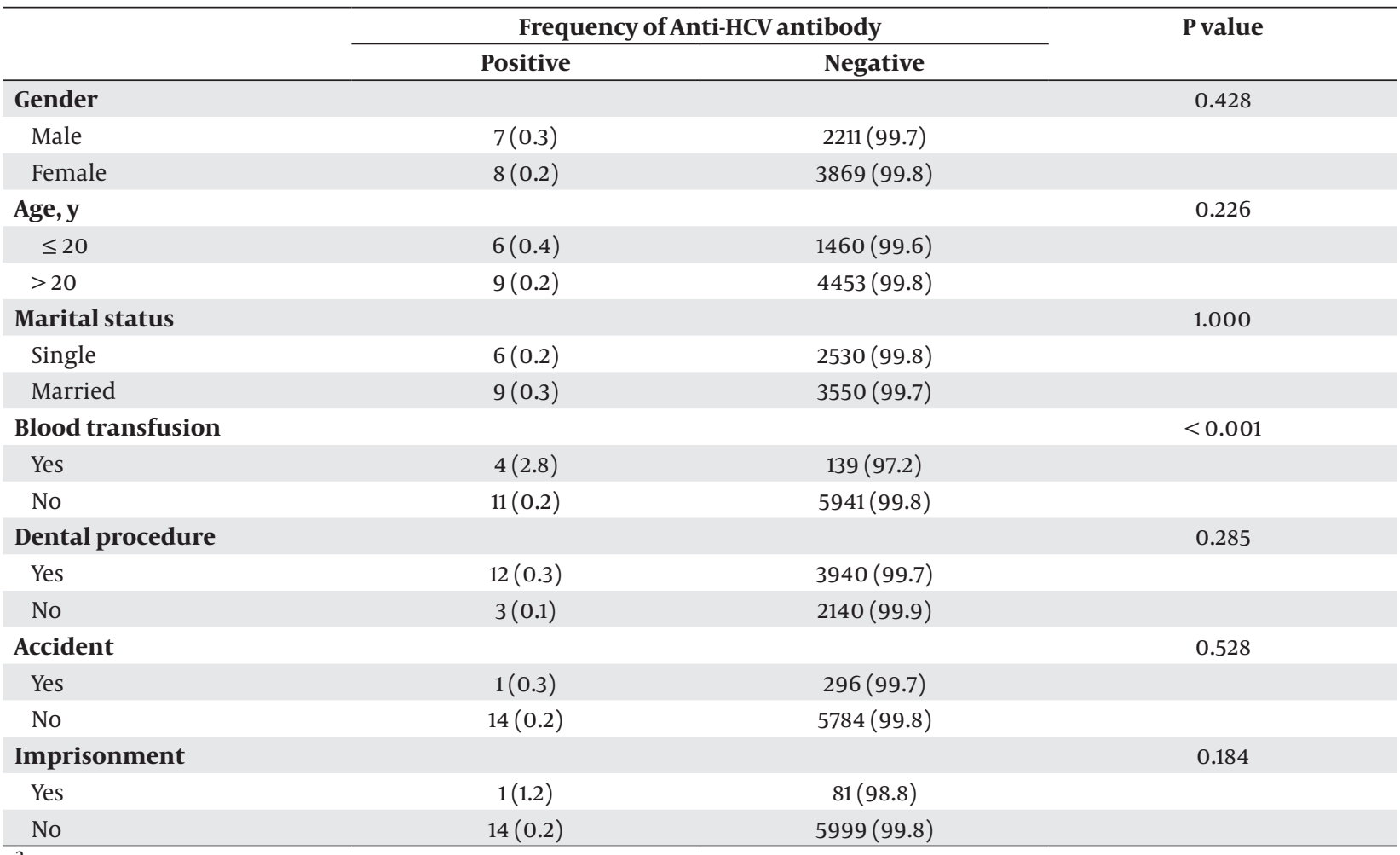

${ }^{\mathrm{a}} \mathrm{P}$ value $<0.05$ is considered as significant.

$\mathrm{b}$ Data are represented as No. (\%).

Among two villages, 3393 and 2702 out of the 6095 participant were native of Akbarabad and Farmashkan with the age range of 83 and 88 years (7-90 and 7-95 years) and the mean age of $32.62 \pm 16.52$ and $36.93 \pm 17.90$ years, respectively. Moreover, the prevalence of persons with positive anti-HCV antibody was 0.35 and $0.11 \%$, respectively. A statistical significant association was found between blood transfusion and anti-HCV antibody positivity in Akbarabad village $(\mathrm{P}<0.001)$. Our analysis also demonstrated that in the Akbarabad village, those with the age $\leq 12$ years old had three-fold higher risk for anti-HCV antibody positivity than other subjects (OR: 3.15, 95\% CI: 0.95-10.44). In addition, the individuals with a history of blood transfusion had 46-fold higher risk for anti-HCV antibody positivity than those with negative history of blood transfusion (OR: 46.41, 95\% CI: 11.18-192.72).

No statistical association was found between the antiHCV antibody positivity and evaluated variables except history of blood transfusion $(\mathrm{P}<0.001)$ in Farmashkan villages $(P>0.05)$. Individuals with a history of blood transfusion had11-fold higher risk for anti-HCV antibody positivity than those with negative history of blood transfusion (OR: 11.40, 95\% CI:1.02-127.21).

\section{Discussion}

This study calculated the prevalence of HCV infection in the general population of the two Kavar villages, Ak- barabad and Farmashkan, and assessed its association with gender, age, marital status, jobs/position and history of some related risk factors. Our participants were rural general populations and most of them were without any known HCV-related risk factors. The general prevalence of HCV in this study was detected as $0.25 \%$ and the highest prevalence was seen in age $\leq 12$ years old ( $1 \%$ ). Although there was a significant association between blood transfusion and anti-HCV antibody positivity, no significant associations were detected between other related risk factors and anti-HCV positivity.

Based on a systematic review in 2009, HCV infection prevalence in general population was calculated as $1.6 \%$ (3) that is much higher that our results. In another study, which performed in the civilian population of the United States, it had been demonstrated that the prevalence of anti-HCV in the United Sates decreased from $1.9 \%$ in 2001to $1.3 \%$ in 2005, and remained stable up to 2010 (12). The total viremic HCV population of Australia in 2012 was estimated at 230000 with a viremic prevalence rate of $1.0 \%$. In addition, the anti-HCV prevalence was estimated at $1.3 \%$, equivalent to 308000 anti-HCV positive individuals (13). Ferthermore, several studies were performed about the prevalence of HCV in the European, American, African and Asian countries. In a study from Austria in 2008 , the anti-HCV prevalence rate of $0.5 \%$ (0.1-0.7\%) was reported (14). In Belgium, different low (0.12\%) and high 
(1.23\%) prevalence rates were reported in two studies performed in 2007 (15) and 2012 (13), respectively. Total seroprevalence of 1.38, 0.96, 0.6,0.63, 12.5, 0.4, 0.5, 2.6, 1.6 and 0.95 \% in Brazil (16), Canada (17), Czech Republic (18), Denmark (19), Egypt (20), England (21), Germany (22),Spain (23), Switzerland (24) and Turkey (25), were also recorded, respectively. Our detected HCV prevalence is lower than all previous reports and approximately near to the reports from England and Germany. Also, our prevalence is similar to a recently report from Mashhad, Iran. In that study, the prevalence of hepatitis $C$ seropositivity in the general population of Mashhad, northeast of Iran, was evaluated and its results demonstrated that the overall seroprevalence of hepatitis C was $0.2 \%$ using the ELISA method (1). Merat et al. reported that the HCV prevalence in Iran is $0.5 \%$ in individuals with age range of $18-65$ years and higher and about $1 \%$ was seen in male (26). This prevalence rate is two-fold higher than our results. The probable reason for this difference may be the nature of two population, the urban population in Merat et al. (26) and Shakeri et al. (1) studies and the rural population in our study. Therefore, the HCV infection related risk factors and consequently anti-HCV antibody prevalence were lower in this study. However, the HCV viral load evaluation using RT-PCR is highly recommended to confirm this difference.

Although, the prevalence of HCV infection in children ranges from 0.05 to $0.4 \%$ (27), the higher prevalence was seen in this study for the persons with age of $\leq 12$ years old (1\%). It is necessary to evaluate the HCV antibody of both children and their mothers to rule out the vertical transmission of HCV. In our study, similar to previous reports from Iran $(1,26)$, the HCV-positive male was dominant in comparison to female ( $0.3 \%$ vs. $0.2 \%$, respectively). However, this difference was not significant and therefore there was no association between gender and antiHCV antibody positivity.

In an Iranian study performed by Kohan et al. in 2006, 11.1\% of HCV infected persons (23 out of 207) co-infected with HBV (28). In our study, the HBV-HCV co-infection was detected in $13.3 \%$ of the persons (two out of 15). These two children were HbsAg positive and HBcAb negative. Also, the high anti-HCV antibody positivity was detected in the student groups (24.8\%) based on the job/position categorization. This can be a warning for Education and Health Ministry for learning mostly about viral hepatitis transmission routes and prevention, especially HBV and HCV.

Transfusion of the infected blood and blood product is one of the major routes of the HCV infection. This is more important in some populations such as thalassemia, hemophilia, and hemodialysis because they are dependent on the blood products during their lifetime. It has been demonstrated that the HCV infection rate in these groups is higher than the normal population (29-40) as demonstrated in our study.

Our study suffered from some limitations including limitations in the univariate analysis and some limita- tions related to the effects of a long-time of the crosssectional study. Also, lack of confirmation of the positive anti-HCV antibody samples with molecular methods, such as PCR and RT-PCR is another limitation. However, this issue is being set up and performed in our center for larger cohort study.

In conclusion, due to this fact that HCV infection is a preventable and curable disease, we recommend more attention for the control of patient-to-patient HCV transmission in hospitals. Although prevalence rate in this study was lower than other studies and no statistical significant associations were found with common risk factors except blood transfusion, paying the especial attention to the all risk factors is seriously advised. Finally, further studies are required in other rural and urban populations for better evaluation of the HCV-infection prevalence and real source of transmission.

\section{Acknowledgements}

The authors wish to thank Miss Maryam Nejabat and Mr. Saeed Amirzadeh for their excellent assistance in gathering the patients' data and performing the laboratory analysis. The study was supported by the Gastroenterohepatology Research Center, Shiraz University of Medical Sciences, Shiraz, IR Iran.

\section{Authors' Contribution}

Study concept and design: Mohammad Reza Fattahi and Seyed Mohammad Kazem Hosseini Asl; Acquisition of data: Faezeh Mohamaddoust, Alireza Safarpour, Masood Sepehrimanesh; Analysis and interpretation of data: Mohammad Reza Fattahi; Drafting of the manuscript: Masood Sepehrimanesh, Faezeh Mohamaddoust, Alireza Safarpour; Critical revision of the manuscript for important intellectual content: Mohammad Reza Fattahi and Seyed Mohammad Kazem Hosseini Asl; Statistical analysis: Masood Sepehrimanesh, Alireza Safarpour; Administrative, technical, and material support: Mohammad Reza Fattahi; Study supervision: Mohammad Reza Fattahi and Seyed Mohammad Kazem Hosseini Asl.

\section{References}

1. Shakeri MT, Nomani H, Ghayour Mobarhan M, Sima HR, Gerayli S, Shahbazi S, et al. The prevalence of hepatitis $C$ virus in mashhad, iran: a population-based study. Hepat Mon. 2013;13(3).

2. Feldman M, Friedman L, Brandt L. Sleisenger and Fordtran's gas trointestinal and liver disease: pathophysiology, diagnosis, management, expert consult premium edition-enhanced online features.: Elsevier Health Sciences; 2010.

3. Alavian SM, Fallahian F. Epidemiology of hepatitis $\mathrm{c}$ in iran and the world. Semj. 2009;10(4):162-72.

4. Mohd Hanafiah K, Groeger J, Flaxman AD, Wiersma ST. Global epidemiology of hepatitis $C$ virus infection: new estimates of age-specific antibody to HCV seroprevalence. Hepatology. 2013;57(4):1333-42.

5. Alavian SM, Ahmadzad-Asl M, Lankarani KB, Shahbabaie MA Kabir A. Hepatitis C infection in the general population of Iran: a systematic review. Hepat Mon. 2009;9(3):211-23. 
6. Jahanbakhsh Sefidi F, Keyvani H, Monavari SH, Alavian SM, Fakhim S, Bokharaei-Salim F. Distribution of hepatitis C virus genotypes in Iranian chronic infected patients. Hepat Mon. 2013;13(1).

7. Rosenthal E, Hazani A, Segal D, Koren A, Kamal S, Rimon N, et al. Lack of transmission of hepatitis $C$ virus in very close family contacts of patients undergoing multitransfusions for thalassemia. J Pediatr Gastroenterol Nutr. 1999;29(1):101-3.

8. Iwarson S, Norkrans G, Wejstal R. Hepatitis C: natural history of a unique infection. Clin Infect Dis. 1995;20(5):1361-70.

9. Flynn JK, Sacks-Davis R, Higgs P, Aitken C, Moneer S, Suppiah V, et al. Detection of HCV-Specific IFN-gamma Responses in HCV Antibody and HCV RNA Negative Injecting Drug Users. Hepat Mon. 2014;14(1).

10. Larney S, Kopinski H, Beckwith CG, Zaller ND, Jarlais DD, Hagan $\mathrm{H}$, et al. Incidence and prevalence of hepatitis $\mathrm{C}$ in prisons and other closed settings: results of a systematic review and metaanalysis. Hepatology. 2013;58(4):1215-24.

11. Tamaddoni A, Mohammadzadeh I, Ziaei O. Seroprevalence of HCV antibody among patients with beta-thalassemia major in Amirkola Thalassemia Center, Iran. Iran J Allergy Asthma Immunol. 2007;6(1):41.

12. Ditah I, Ditah F, Devaki P, Ewelukwa O, Ditah C, Njei B, et al. The changing epidemiology of hepatitis $C$ virus infection in the United States: National Health and Nutrition Examination Survey 2001 through 2010. J Hepatol. 2014;60(4):691-8.

13. Bruggmann P, Berg T, Ovrehus AL, Moreno C, Brandao Mello CE, Roudot-Thoraval F, et al. Historical epidemiology of hepatitis C virus (HCV) in selected countries. J Viral Hepat. 2014;21 Suppl 1(s1):5-33.

14. Hope VD, Eramova I, Capurro D, Donoghoe MC. Prevalence and estimation of hepatitis B and C infections in the WHO European Region: a review of data focusing on the countries outside the European Union and the European Free Trade Association. Epidemiol Infect. 2014;142(2):270-86.

15. Quoilin S, Hutse V, Vandenberghe H, Claeys F, Verhaegen E, De Cock L, et al. A population-based prevalence study of hepatitis A, $\mathrm{B}$ and $\mathrm{C}$ virus using oral fluid in Flanders, Belgium. Eur J Epidemiol. 2007;22(3):195-202.

16. Pereira LM, Martelli CM, Moreira RC, Merchan-Hamman E, Stein AT, Cardoso MR, et al. Prevalence and risk factors of Hepatitis C virus infection in Brazil, 2005 through 2009: a cross-sectional study. BMC Infect Dis. 2013;13:60.

17. Rotermann M, Langlois K, Andonov A, Trubnikov M. Seroprevalence of hepatitis B and C virus infections: Results from the 2007 to 2009 and 2009 to 2011 Canadian Health Measures Survey. Health Rep. 2013;24(11):3-13.

18. Nemecek V, Castkova J, Fritz P, Linhartova A, Svandova E, Sramova $\mathrm{H}$, et al. The 2001 serological survey in the Czech Republic--viral hepatitis. Cent Eur J Public Health. 2003;11 Suppl:S54-61.

19. Christensen PB, Hay G, Jepsen P, Omland LH, Just SA, Krarup HB et al. Hepatitis C prevalence in Denmark -an estimate based on multiple national registers. BMC Infect Dis. 2012;12:178.

20. Ray SC, Arthur RR, Carella A, Bukh J, Thomas DL. Genetic epidemiology of hepatitis C virus throughout egypt. J Infect Dis. 2000;182(3):698-707.

21. Harris RJ, Ramsay M, Hope VD, Brant L, Hickman M, Foster GR, et al. Hepatitis $C$ prevalence in England remains low and varies by ethnicity: an updated evidence synthesis. Eur J Public Health. 2012;22(2):187-92.

22. Volzke H, Schwahn C, Wolff B, Mentel R, Robinson DM, Kleine V, et al. Hepatitis $B$ and $C$ virus infection and the risk of atheroscle- rosis in a general population. Atherosclerosis. 2004;174(1):99-103.

23. Sola R, Cruz De Castro E, Hombrados M, Planas R, Coll S, Jardi R, et al. [Prevalence of hepatitis B and hepatitis $C$ viruses in different counties of Catalonia, Spain: cross-sectional study]. Med Clin (Barc). 2002;119(3):90-5.

24. Sagmeister M, Renner EL, Mullhaupt B, Wong JB. Simulation of hepatitis $C$ based on a mandatory reporting system. Eur J Gastroenterol Hepatol. 2002;14(1):25-34.

25. Tozun N, Ozdogan OC, Cakaloglu Y, Idilman R, Karasu Z, Akarca US. A nationwide prevalence study and risk factors for hepatitis A, B, C and D infections in Turkey. Turkish Association for the Study of the Liver. 2010;32(3).

26. Merat S, Rezvan H, Nouraie M, Jafari E, Abolghasemi H, Radmard AR, et al. Seroprevalence of hepatitis C virus: the first populationbased study from Iran. Int J Infect Dis. 2010;14 Suppl 3:e113-6.

27. Ahmad A. B. , Keeffe E. Hepatitis $C$ virus infection. In: Yamada TH, Alpers DN, Kalloo A, Kaplowitz N, editors. Textbook of gastroenterology. 5 th ed;2009.

28. Kohan N, Zandieh T, Samiei SH, Ataie Z, Kavari M. The prevalence and clinical significance of hepatitis B and C coinfection. Iran J Med Sci. 2006.

29. Assarehzadegan MA, Ghafourian Boroujerdnia M, Zandian K. Prevalence of hepatitis $\mathrm{B}$ and $\mathrm{C}$ infections and HCV genotypes among haemophilia patients in ahvaz, southwest iran. Iran Red Crescent Med J. 2012;14(8):470-4.

30. Borhany M, Shamsi T, Boota S, Ali H, Tahir N, Naz A, et al. Transfusion transmitted infections in patients with hemophilia of Karachi, Pakistan. Clin Appl Thromb Hemost. 2011;17(6):651-5.

31. El-Faramawy AA, El-Rashidy OF, Tawfik PH, Hussein GH. Transfusion transmitted hepatitis: where do we stand now? A one center study in upper egypt. Hepat Mon. 2012;12(4):286-91.

32. Gonzalez R, Torres P, Castro E, Barbolla L, Candotti D, Koppelman M, et al. Efficacy of hepatitis B virus (HBV) DNA screening and characterization of acute and occult HBV infections among blood donors from Madrid, Spain. Transfusion. 2010;50(1):221-30.

33. Haidar NA. Prevalence of hepatitis B and hepatitis C in blood donors and high risk groups in Hajjah, Yemen Republic. Saudi Med J. 2002;23(9):1090-4.

34. Elizee PK, Alavian SM, Miri SM, Behnava B, Alavian SH, Keshvari M, et al. The seroprevalence of entrically transmitted viral hepatitis in hcv infected thalassemia and hemophilia patients in iran. Jundishapur J Microb. 2013;6(7).

35. Arababadi MK, Nasiri Ahmadabadi B, Yousefi Daredor H, Kennedy D. Epidemiology of occult hepatitis B infection among thalassemic, hemophilia, and hemodialysis patients. Hepat Mon. 2012;12(5):315-9.

36. Khattak MF, Salamat N, Bhatti FA, Qureshi TZ. Seroprevalence of hepatitis B, C and HIV in blood donors in northern Pakistan.J Pak Med Assoc. 2002;52(9):398-402.

37. Mittal M, Zaman S, Bhatnagar N, Gajjar M. Transfusion transmitted infections in patients with hemophilia: A study from a tertiary care hospital in western india. IJID . 2013;12(1).

38. Orman ES, Fried MW. Hepatitis $C$ viral infection in patients with hemophilia and hemolytic disorders. Clin Liver Dis. 2012;1(3):95-7.

39. Valizadeh N, Nateghi S, Noroozi M, Hejazi S, Aghanezhad F, Ali AA. Seroprevalence of hepatitis C, hepatitis B and HIV viruses in hemophiliacs born 1985-2010 in west Azarbaijan of Iran. Asian J Transfus Sci. 2013;7(1):55-8.

40. Yazdani MR, Kassaian N, Ataei B, Nokhodian Z, Adibi P. Hepatitis $C$ virus infection in patients with hemophilia in Isfahan, Iran. Int JPrev Med. 2012;3(Suppl 1):S89-93. 